\title{
On the Pterosaur Remains from the Río Belgrano Formation (Barremian), Patagonian Andes of Argentina
}

\author{
ALEXANDER W.A. KELLNER ${ }^{1}$, MARÍA B. AGUIRRE-URRETA ${ }^{2}$ and VICTOR A. RAMOS ${ }^{2}$ \\ ${ }^{1}$ Setor de Paleovertebrados, Departamento de Geologia e Paleontologia, Museu Nacional/UFRJ \\ Quinta da Boa Vista, s/n, São Cristóvão, 20940-040 Rio de Janeiro, RJ, Brasil \\ ${ }^{2}$ Laboratorio de Tectónica Andina, Departamento de Geología, Universidad de Buenos Aires \\ Ciudad Universitaria, Pabellon II, 1428 Buenos Aires, Argentina
}

Manuscript received on March 26, 2002; accepted for publication on May 7, 2003; contributed by ALEXANDER W.A. KELLNER*

\begin{abstract}
Pterosaur remains from the Río Belgrano Formation, Santa Cruz Province, Argentina, were found close to the Estancia Río Roble, along with several ammonoids that indicate a Barremian age for those strata. The specimens (MACN-SC 3617) consist of one ulna and one element tentatively identified as a portion of a wing metacarpal. The ulna shows morphological affinities with the Pteranodontoidea (sensu Kellner 1996), particularly with the members of the Anhangueridae by having a well developed ventral crest close to the proximal articulation, and is tentatively referred to this pterosaur clade. The oldest record of the Anhangueridae, previously limited to the Aptian/Albian, is therefore extended to the Barremian. The Argentinean material is preserved in three dimensions, an unusual condition for pterosaur fossils from that country, indicating that the site situated near the Estancia Río Roble has a great potential for new and well preserved specimens.
\end{abstract}

Key words: Pterosauria, Río Belgrano Formation, Lower Cretaceous, Argentina.

\section{INTRODUCTION}

The systematic geological survey of the southern Patagonian Andes done through the Servicio Geológico Nacional during the early eighties identified an important fossil locality of Cretaceous age in the region of the Belgrano Lake, approximately $48^{\circ} \mathrm{S}$ latitude. Although the fossil assemblage is dominated by ammonoids, some remains of pterosaurs were found in 1981 (Aguirre-Urreta and Ramos 1981). The material consists of two bones that were only briefly mentioned in the literature (Montanelli 1987, Bonaparte 1996).

\footnotetext{
* Member of Academia Brasileira de Ciências Correspondence to: Alexander W.A. Kellner E-mail: kellner@mn.ufrj.br
}

The fossils were found along the Chorrillo Rivera, a small stream of the Roble river system, a few kilometers south of the Belgrano Lake in the province of Santa Cruz (Figure 1). The access to the area is done from the national road 40 to Estancia Río Roble, distant approximately $95 \mathrm{~km}$. The nearest town is Gobernador Gregores situated about $140 \mathrm{~km}$. The fossil locality is $5 \mathrm{~km}$ south of the Estancia Río Roble.

The purpose of this paper is to describe those pterosaur remains and document their precise geographic and stratigraphic location, and to constrain the age of the vertebrate horizon using the abundant micro and megafauna found at the site. 

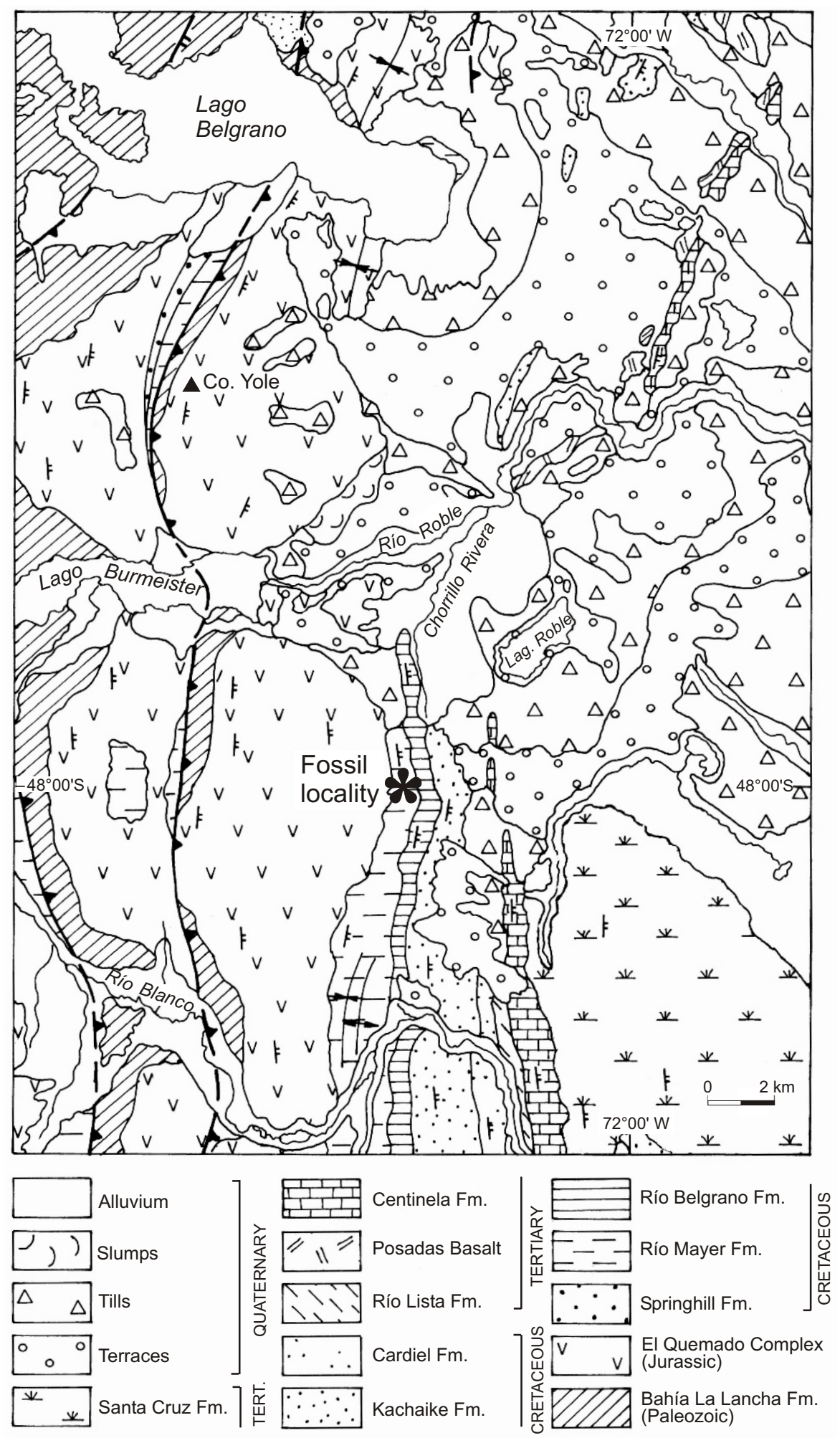

Fig. 1 - Location of the site with pterosaur remains in Santa Cruz Province, Argentina. 


\section{GEOLOGIC SETTING}

The southern Patagonian Andes are characterized by a low-grade metamorphic core of Late Paleozoic age, emplaced by a series of arc related granitoids of Mesozoic and Cenozoic age. These metamorphic rocks were part of an accretionary prism developed during the Late Paleozoic along the western Pacific margin of Gondwana. Volcanic rocks of Jurassic age unconformably overly the previous rocks, deposited during the beginning of the Andean subduction along the western margin of Gondwana, coeval with the opening of the South Atlantic. At this stage a series of transgressive and regressive cycles from the Pacific sea characterizes a retroarc basin where important accumulations of continental and marine deposits are recorded during the Cretaceous. Final uplift during the Cenozoic produced the present Patagonian fold and thrust belt (Ramos 1989) where the fossiliferous rocks are found.

\section{CRETACEOUS STRATIGRAPHY}

A sequence of black shales of the Río Mayer Formation paraconformably overlies the Jurassic rocks (Figure 2). These rocks were deposited in a low energy marine platform environment, with restricted circulation, away from the littoral. About $50 \mathrm{~m}$ from the base of the sequence the first fossil level is found. Fossils in these rocks are preserved in ellipsoidal concretions and septarias, which indicate a reducing environment. The concretions vary from a few centimeters up to one meter in size.

Thin limestone beds of 5 to $7 \mathrm{~cm}$ in thickness are interfingered with the shales bearing small bivalves. Green sandstones are interfingered with the black shales, as small turbiditic layers with convolute sedimentation. Two other levels of fossiliferous concretions are at the top of this $175 \mathrm{~m}$ thick sequence of black shales (Figure 2).

The green sandstones of the Río Belgrano Formation are transitionally deposited over the black shales. The base of the unit is indicated by a $3 \mathrm{~m}$ thick bed of sandstone. The sandstones have parallel bedding, organized in coarsening-up sequences,

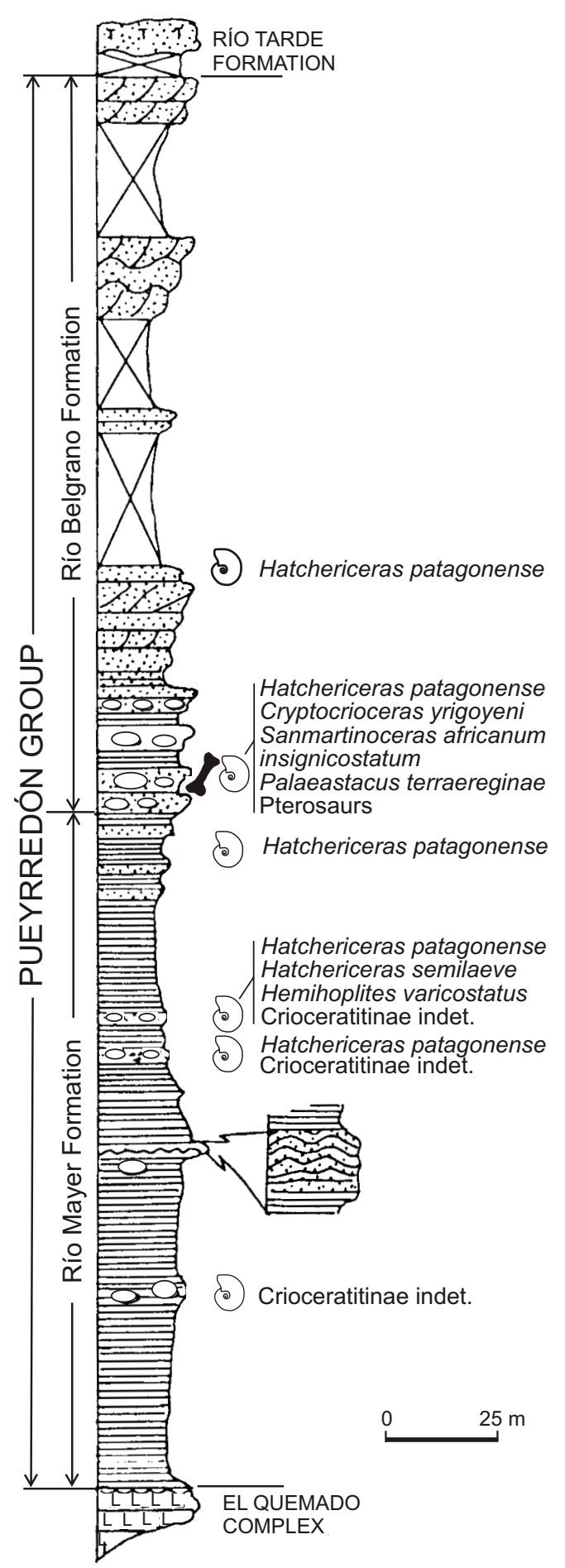

Fig. 2 - Stratigraphic section of the Río Roble area, showing the fossil horizons (modified from Aguirre-Urreta and Ramos 1981). 
with green brownish shales at the base. Epidiagenetic red sandy concretions are common a few meters above the contact with the underlying Río Mayer Formation, and constitute the fourth fossiliferous level. Ammonoids, crustacean decapods and the pterosaur bones were found in this level. Bioturbation increases towards the top of the green sandstones, and laminar bedding gives place to cross laminated beds. Cut and fill structures become common and at the top, a coarse brown red sandstone marks the contact with the basal beds of the Kachaike Formation.

The green sandstones of the Río Belgrano Formation show the beginning of the marine regression in the area. Facies indicate the transition to a littoral near coast high energy environment, up to the continental fluvial deposits of the Kachaike Formation.

The pterosaur remains were found in a nearshore environment, which to the top shows an even higher energy facies that finally changes to fluviatile continental facies. This occurrence corroborates with the hypothesis that pterosaur colonized marginal-marine deposits (Kellner 1994).

\section{BIOSTRATIGRAPHIC CONTROLS}

The ammonoids recovered in the Río Mayer and Río Belgrano Formations at Chorrillo Rivera are mostly Hatchericeras Stanton, represented by several species. In the same level as the pterosaur remains, the ammonoids are dominated by Hatchericeras patagonense Stanton, associated with Cryptocrioceras yrigoyeni (Leanza), and Sanmartinoceras africanum insignicostatum Riccardi, AguirreUrreta and Medina, and decapod crustaceans. In Patagonia, this association represents the Hatchericeras patagonense assemblage zone of the Lower Barremian (Riccardi 1984). The three species are known from Patagonia and Zululand only. In South Africa, H. patagonense and C. yrigoyeni are known from the Barremian I of Kennedy and Klinger (1975) equivalent to the Lower Barremian. Sanmartinoceras africanum has been reported from the Upper Barremian, associated with Colchidites vulanensis australis. This latter species distinctively overlies the Hatchericeras fauna in Patagonia and characterizes the C. vulansis assemblage zone of the Upper Barremian (Riccardi 1984). Based on the evidence presented above, the Hatchericeras patagonense assemblage zone can be placed in the Lower-Middle Barremian.

\section{PTEROSAUR REMAINS}

The pterosaur material was found at a locality $5 \mathrm{~km}$ to the south of the Estancia Río Roble and consists of two long bones. Despite being incomplete, both are preserved in three dimensions, a rare condition among pterosaur fossils, and show no signs of distortion. Both are housed at the Museo Argentino de Ciencias Naturales "Bernardino Rivadavia" (MACN, Buenos Aires) and were cataloged under the number MACN-SC 3617. It should be noted that it is not sure whether both belong to the same individual.

The least complete (Fig. 3) is a long bone that lacks any articulation, making its identification difficult. The total preserved length is $197 \mathrm{~mm}$, with the mid-section of the shaft compressed laterally $(20 \times 16 \mathrm{~mm})$. The widest part has a length of $44 \mathrm{~mm}$ and is more expanded than the shaft, indicating that it was close to an articulation. Most of the external surface was broken away, but where observable, the bone walls are very thin with an average thickness of about $1 \mathrm{~mm}$. In some parts, the internal trabecular structure can be observed, particularly close to the expanded area. This element was previously identified as a radius (Bonaparte 1996), but no feature is present that could confirm this. Furthermore, this bone seems rather robust for a radius. Due to its general shape and size, it can be rather identified as a first wing phalanx (F1D4) or the proximal portion of the fourth wing metacarpal (McIV); based on the expanded portion (less expanded than the proximal articulation of most known F1D4) the latter interpretation is favored here.

The second and most complete element is a left ulna, as identified by Bonaparte (1996). It is com- 

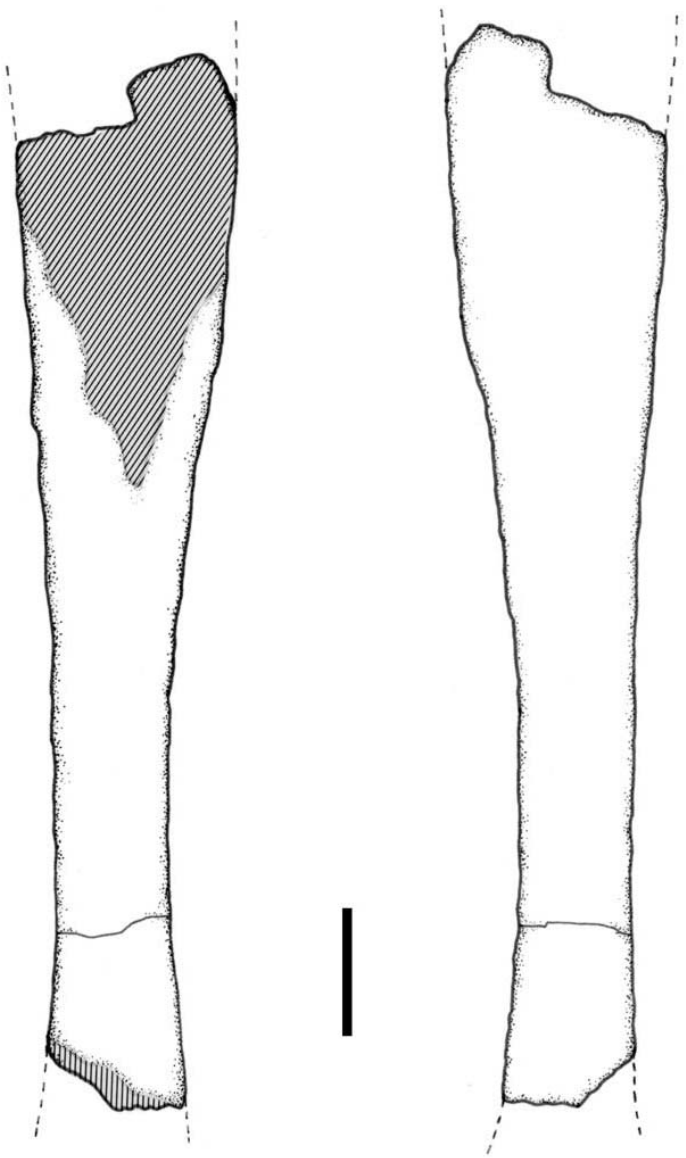

Fig. 3 - Drawings of an isolated bone (wing metacarpal? MACN-SC 3617) found in the Río Belgrano Formation (Barremian), Santa Cruz Province (Argentina). Scale bar: $3 \mathrm{~cm}$.

posed of the distal articulation and most of the shaft, but lacks the proximal portion, with a total preserved length of $199 \mathrm{~mm}$ (Figs. 4 and 5). As common of pterosaur ulnae (particularly in pterodactyloids), this bone is compressed anteroposteriorly and has an elliptical circumference at the middle portion of the shaft $(17,5 \times 12 \mathrm{~mm})$. It is a hollow structure with the bone wall very thin (average thickness around $1 \mathrm{~mm}$ ). In some places the surface was broken off, revealing the presence of a well developed internal trabecular structure. In lateromedial view, this bone shows a concave dorsal margin and a straighter ventral margin that becomes concave near the articulations.

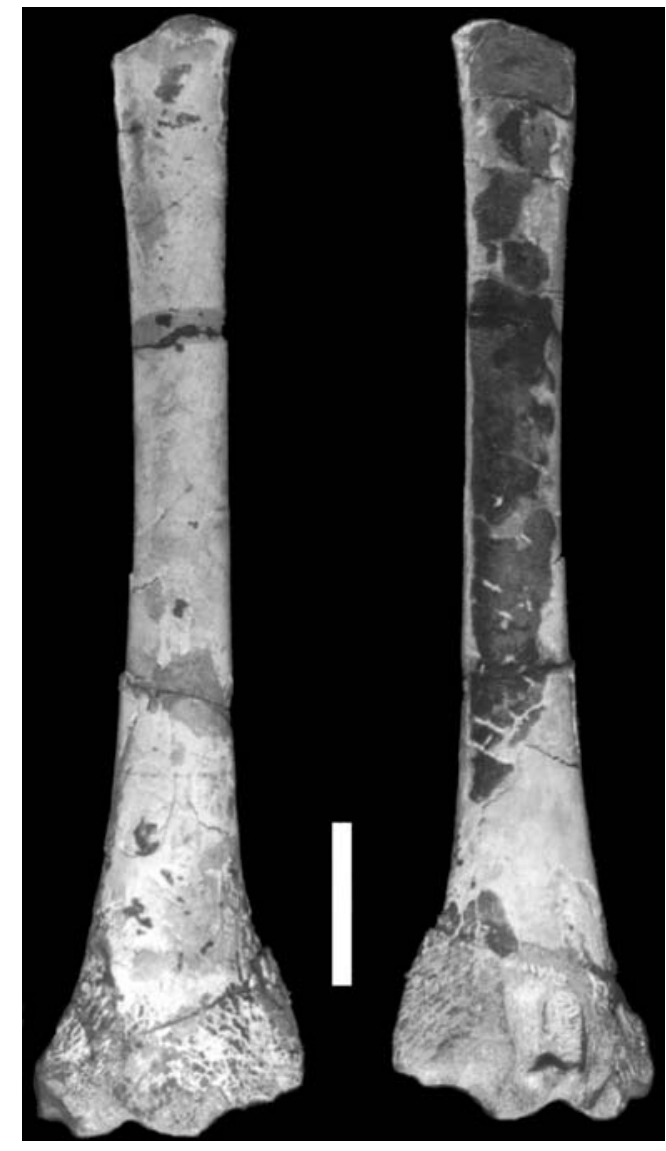

Fig. 4 - Photographs of a left ulna (MACN-SC 3617), from the Río Belgrano Formation (Barremian), Santa Cruz Province (Argentina) in (a) anterior and (b) posterior views. Scale bar: $3 \mathrm{~cm}$.

The distal articulation is expanded (maximum width $49,2 \mathrm{~mm}$ ), with the dorsal portion wider than the ventral part. Close to the articulation on the anterior side, part of the bone was broken off possibly prior to fossilization since it is filled with matrix. Whether this breakage was caused by scavenging or during the embedding process cannot be determined.

The articulation of the distal surface shows several pits and has a porous aspect, suggesting that the epiphyseal cartilage was not fully ossified in this specimen. Neither the tuberculum nor the fovea carpalis are very well developed. Those features suggest that this bone belonged to a young animal (perhaps a sub-adult).

Among the most interesting features of this el- 


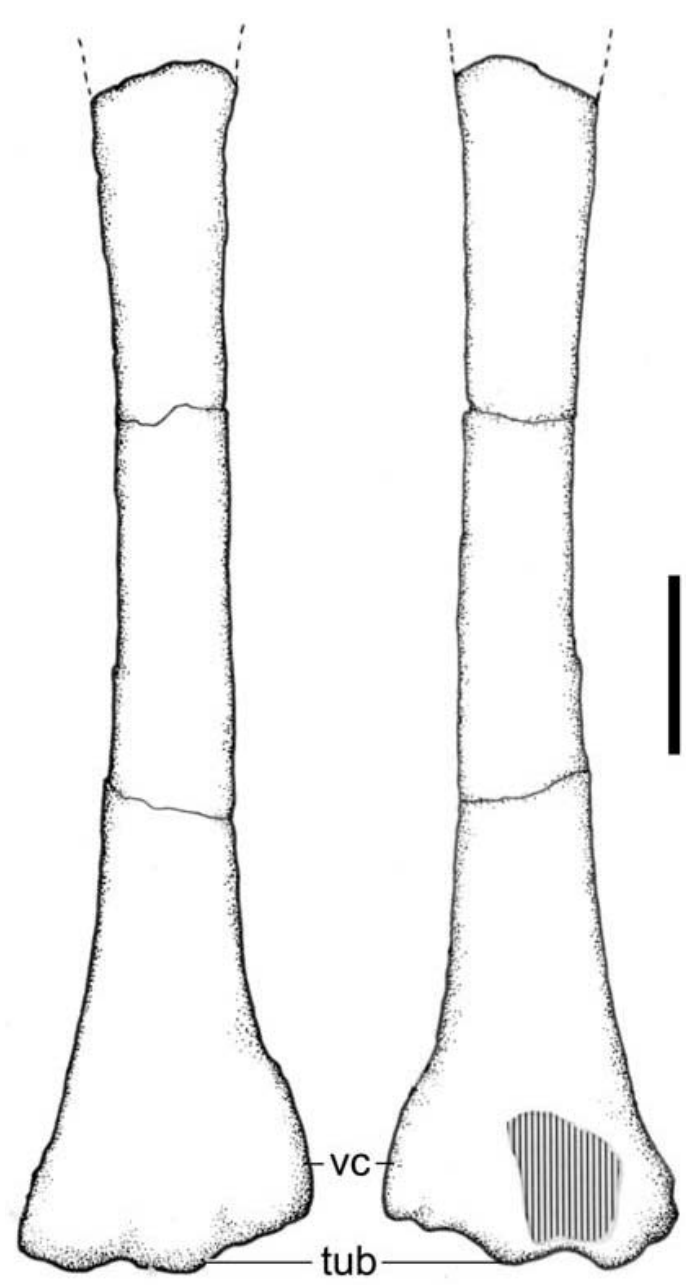

Fig. 5 - Drawings of the left ulna (MACN-SC 3617) from the Río Belgrano Formation (Barremian), Santa Cruz Province (Argentina) in (a) anterior and (b) posterior views. Scale bar: $3 \mathrm{~cm}$. Abbreviations: tub - tuberculum; vc - ventral ridge.

ement is the presence of a well developed ventral ridge. To date, only taxa of the Anhangueridae shows such a feature, which is more developed in the Argentinean specimen (see discussion).

\section{COMPARISONS}

Despite the fact that the pterosaurian nature of the specimens found in the Río Belgrano Formation is indisputable (e.g., extremely thin-walled pneumatic bones), the classification of isolated postcranial elements can be quite challenging. The Belgrano speci-

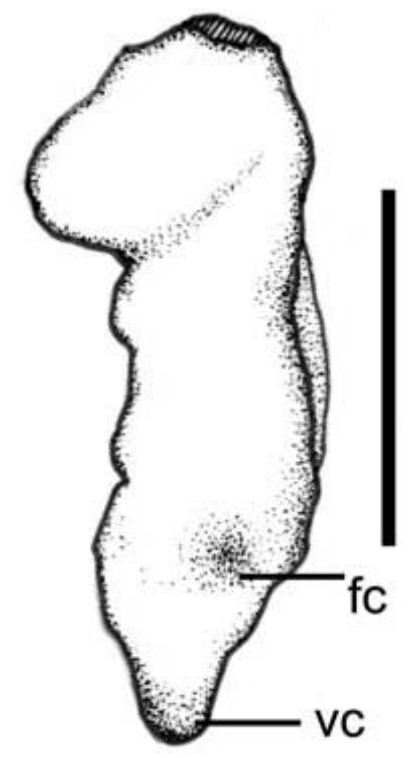

Fig. 6-View of the distal articulation of the left ulna (MACN-SC 3617). Scale bar: $3 \mathrm{~cm}$. Abbreviations: $\mathrm{fc}-$ fovea carpalis; $\mathrm{vc}-$ ventral ridge.

mens clearly belong to large animals. Up to date, the more primitive members of the Pterosauria (i.e., all non-pterodactyloids) are comparatively small, with wingspans less than 2 meters. The maximum estimation of the ulna of the largest reported specimen of Rhamphorhynchus (member of the Rhamphorhynchidae, the sister-taxon of the Pterodactyloidea) is about $115 \mathrm{~mm}$ (see Wellnhofer 1975). This size is less than half the size estimated for the ulna from the Río Belgrano Formation (estimated length: $282 \mathrm{~mm}$ ), suggesting that the Argentinean material represents a member of the clade Pterodactyloidea.

According to Kellner (1996, 1997), the Pterodactyloidea can be divided into two groups: the Archaeopterodactyloidea and the Dsungaripteroidea. Again, based on the size and the general morphology of the ulna (i.e., greater expansion of the distal end), the pterosaur material from the Río Belgrano Formation can be excluded from the Archaeopterodactyloidea, which includes taxa such as Pterodactylus, Germanodactylus, and Gallodactylus (see Kellner 1996, 1997). The same differences apply to the Argentinean genus Pterodaustro, from the Lower Cre- 
taceous strata of the Sierra de las Quijadas of San Luis (Bonaparte 1996, Chiappe et al. 2000), whose ulna is less than half the size of the Belgrano specimen.

The Dsungaripteroidea includes the following clades: Nyctosauridae, Pteranodontoidea, and Tapejaroidea. Among those, the ulna of the Río Belgrano Formation shows more affinities with the pteranodontoid clade Anhangueridae, that (where known) shows a well developed ventral ridge on the distal end of the ulna (more developed in the Argentinean specimen). Such a feature is absent in tapejaroids like Tupuxuara and Quetzalcoatlus (Kellner pers. observ.) and in the pteranodontoids Pteranodon (Bennett 2001) and Istiodactylus (Hooley 1913; recently renamed by Howse et al. 2001). The Argentinean ulna also lacks any evidence of a pneumatic foramen on the posterior side, which is present in Pteranodon (Bennett 2001). Furthermore, the ulna from the Río Belgrano Formation has the dorsal edge of the distal articulation well developed and dorsally expanded, which is also found in anhanguerids. In the Argentinean material, however, this dorsal edge is less developed than in Anhanguera araripensis (see Wellnhofer 1985: p. 122) and Anhanguera piscator.

A gross estimate of the wingspan of the pterosaur from the Río Belgrano Formation can be obtained by the comparison of the ulna with the one known from Anhanguera piscator, the most complete anhanguerid known (Kellner and Tomida 2000). Based on direct comparisons, the complete ulna of the Argentinean form was around $282 \mathrm{~mm}$, which would correspond to an anhanguerid with a wingspan of approximately 3.6 meters. This corresponds to a large but not gigantic member of this pterosaur clade.

\section{CONCLUSIONS}

The pterosaur record in South America is meager (Kellner 2001) and therefore any new occurrence is of interest and should be documented. The ulna found in the Río Belgrano Formation shows some affinities with the Anhangueridae, sharing with the member of this clade a well developed ventral ridge, that is absent in other pterodactyloids. Based on this feature the Belgrano specimen is here regarded as representing either a member of this clade or at least a closely related taxon.

To date, anhanguerids have been found in the following deposits: Aptian/Albian KhurenDikh, Central Mongolia (Bakhurina and Unwin 1995, Kellner and Tomida 2000); Albian strata of the Romualdo Member (Santana Formation), Araripe Basin (e.g., Campos and Kellner 1985, Wellnhofer 1991); late Albian strata of the Paw Paw Formation, Texas (Lee 1994, Kellner and Tomida 2000); Cenomanian strata of Ksar es Souk, Morocco (Mader and Kellner 1999), and Cenomanian Cambridge Greensand Formation, United Kingdom (Kellner 1990). Therefore the Argentinean material further extends the anhanguerid record to the Barremian.

Despite being incomplete, both pterosaur bones show no signs of compaction and are preserved in three dimensions, contrasting with most pterosaur material found in Argentina (Chiappe et al. 2000) and in most deposits (Kellner 1994). So far, such well preserved pterosaur specimens have been reported in abundance only in a few deposits like the Early Cretaceous Strata of the Dsungari Basin in China (e.g., Young 1973) and the Early Cretaceous Romualdo Member (Santana Formation) of the Araripe Basin (e.g, Price 1971, Wellnhofer 1985, Campos and Kellner 1985). The material described here indicates that the site close to the Estancia Río Roble has a great potential for new and well preserved finds of those volant archosaurs.

\section{ACKNOWLEDGMENTS}

The authors wish to thank Dr. J.F. Bonaparte (MACN, Buenos Aires) for access to the specimens under his care and Maurílio Silva de Oliveira (Museu Nacional/UFRJ) for the drawings. Three unknown reviewers are thanked for several suggestions that improved the manuscript. A.W.A. Kellner wishes to acknowledge the Conselho Nacional de Desenvolvi- 
mento Científico e Tecnológico (CNPq, Brasília) and the Fundação Carlos Chagas Filho de Amparo à Pesquisa do Estado do Rio de Janeiro (FAPERJ, Rio de Janeiro) for partially funding the projects on Mesozoic archosaurs under his coordination.

\section{RESUMO}

Restos de pterossauros da Formação Río Belgrano, Santa Cruz, Argentina são descritos. O material foi encontrado nas proximidades da Estancia Río Roble, associado com diversos ammonóides que sugerem uma idade Barremiana para estas camadas. O material consiste de dois ossos longos (MACN-SC 3617), formados por uma ulna e o outro tentativamente identificado como parte de uma metacarpo alar. A ulna apresenta semelhanças morfológicas com os Pteranodontoidea (sensu Kellner 1996), sobretudo com membros de Anhangueridae devido a presença de uma crista ventral próxima a articulação proximal, sendo referida à este clado. O registro mais antigo de Anhangueridae, previamente limitado para o Aptiano/Albiano, é extendido ao Barremiano. O material argentino está preservado em três dimensões sem maiores distorções, que é raro nos registros de pterossauros daquele país, indicando que a localidade situada perto da Estancia Río Roble tem grande potencial para o encontro de restos destes animais voadores bem preservados.

Palavras-chave: Pterosauria, Formação Río Belgrano, Cretáceo Inferior, Argentina.

\section{REFERENCES}

Aguirre-Urreta MB and Ramos VA. 1981. Estratigrafía y Paleontología de la Alta Cuenca del río Roble, Cordillera Patagónica. VIII Congreso Geológico Argentino, Actas III, Buenos Aires, 101-138.

BAKHURINA NN AND Unwin DM. 1995. A survey of pterosaurs from the Jurassic and Cretaceous of the former Soviet Union and Mongolia. Historical Biology 10: 197-245.

BennetT SA. 2001. The osteology and functional morphology of the Late Cretaceous pterosaur Pteranodon Part 1. Palaeontographica ser A 260: 1-112.

Bonaparte JF. 1996. Cretaceous tetrapods of Argentina. Münchner Geowiss Abh München ser A 30: 73-130.
Campos DA and Kellner AWA. 1985. Panorama of the flying reptiles study in Brazil and South America. An Acad Bras Cienc 57: 453-466.

Chiappe LM, Kellner AWA, Rivarola D, Davila S AND Fox M. 2000. Cranial morphology of Pterodaustro guinazui (Pterosauria: Pterodactyloidea) from the Lower Cretaceous of Argentina. Contributions in Science 483: 1-19.

Hooley RW. 1913. On the skeleton of Ornithodesmus latidens; an ornithosaur from the Wealden shales of Atherfield (Isle of Wight). Quat Jour Geol Soc London 69: 372-422.

Howse SCB, Milner AR And Martill D. 2001. Pterosaurs. In: Martill D AND NAish D (Ed), Dinosaurs of the Isle of Wight, Paleontological Association Field Guides to Fossils, n. 10, London: Paleontological Association, p. 324-335.

Kellner AWA. 1990. Os répteis voadores do Cretáceo brasileiro. In: ANUÁRIO do INSTITUTO DE GEOCIÊNCIAS 1989, Rio de Janeiro: UFRJ, p. 86-106.

KELLNER AWA. 1994. Remarks on pterosaur taphonomy and paleoecology. Acta Geologica Leopoldensia 39: 175-189.

Kellner AWA. 1996. Description of new material of Tapejaridae and Anhangueridae (Pterosauria, Pterodactyloidea) and discussion of pterosaur phylogeny, $\mathrm{PhD}$. Thesis, Columbia University, 347 p. (available through UMI - University Microfilms International).

Kellner AWA. 1997. A new hypothesis of pterosaur phylogeny. In: II Simpósio SOBRE A BACIA do ARARIPE E baCias INTERIORES do Nordeste, Resumo das Comunicações, p. 41. Crato, Ceará.

Kellner AWA. 2001. A review of the pterosaur record from Gondwana. In: Two Hundred Years of PteROSAURS. Strata, sér. 1, vol. 11, Toulouse, France, p. 51-53.

Kellner AWA AND Tomida Y. 2000. Description of a new species of Anhangueridae (Pterodactyloidea) with comments on the pterosaur fauna from the Santana Formation (Aptian-Albian), Northeastern Brazil. National Science Museum Monographs 17: 1-135.

Kennedy WJ And Klinger HC. 1975. Cretaceous faunas from Zululand and Natal, South Africa. Introduction, stratigraphy. Bull British Mus Nat Hist ser. Geology 25: 263-315. 
LEE YN. 1994. The Early Cretaceous pterodactyloid pterosaur Coloborhynchus from North America. Paleontology 37: 755-763.

Mader BJ ANd Kellner AWA. 1999. A new anhanguerid pterosaur from the Cretaceous of Morocco. Bol Museu Nacional ser. Geologia 45: 1-11.

Montanelli SB. 1987. Presencia de Pterosauria (Reptilia) en la Formación La Amarga (HauterivianoBarremiano), Neuquén, Argentina. Ameghiniana 24: 109-113.

PrICE LI. 1971. A presença de pterosauria no Cretáceo Inferior da chapada do Araripe, Brasil. An Acad Bras Cienc 43 (supl.): 452-461.

Ramos VA. 1989. Foothills structure in Northern Magallanes Basin, Argentina. American Association Petroleum Geologists, Tulsa, Bulletin 73: 887-903.
RiCCARDI AC. 1984. Las asociaciones de amonitas del Jurásico y Cretácico de la Argentina. IX Congreso Geológico Argentino, Buenos Aires, Actas IV, 559595.

Wellnhofer P. 1975. Die Rhamphorhynchoidea (Pterosauria) der Oberjura-Plattenkalke Süddeutschlands. Palaeontographica ser. A 148: 132-186.

Wellnhofer P. 1985. Neue Pterosaurier aus der Santana Formation (Apt) der Chapada do Araripe, Brasilien. Palaeontographica ser. A 187: 105-182.

Wellnhofer P. 1991. Weitere Pterosaurierfunde aus der Santana Formation (Apt) der Chapada do Araripe, Brasilien, Palaeontographica ser. A 215: 43-101.

Young CC. 1973. (Reports of Paleontological Expedition to Sinkian (II). Pterosaurian Fauna from Wuerho, Sinkiang). Memoirs of the Inst Vert Paleont Paleoanthro Academia Sinica 11: 18-35 (in Chinese). 